\title{
COMPARATIVE EVALUATION OF BOLUS ADMINISTRATION OF ESMOLOL VERSUS LIGNOCAINE FOR PRESSOR RESPONSE ATTENUATION DURING LARYNGOSCOPY AND ENDOTRACHEAL INTUBATION
}

\author{
Sambasiva Rao Jupalli', Sridhar I², Kiran Madhala ${ }^{3}$ \\ ${ }^{1}$ Assistant Professor, Department of Anaesthesiology, Osmania General Hospital, Hyderabad. \\ ${ }^{2}$ Assistant Professor, Department of Pharmacology, GMC, Nizamabad. \\ ${ }^{3}$ Assistant Professor, Department of Anaesthesiology, GMC, Nizamabad.
}

\section{ABSTRACT}

\section{BACKGROUND}

Endotracheal intubation and anaesthesia have become an integral part of the anaesthesiologist's contribution to the patient care. Endotracheal intubation is the translaryngeal placement of endotracheal tube into the trachea. General anaesthesia procedures involve many stressful events at various stages. There are certainly more stressful situations for the patient under general anaesthesia in regard to induction, intubation and extubation.

Aims and Objectives- A comparative clinical evaluation of intravenous 2\% Lignocaine and Esmolol in attenuating the cardiovascular changes to laryngotracheal stimulation in healthy normotensive patients during a widely used method of induction of anaesthesia in order to reduce the life-threatening complications in susceptible patients.

\section{MATERIALS AND METHODS}

A randomised controlled study was conducted at Osmania General Hospital. The sample size per group is 26. So, the minimum sample size required for the study is 54 . In this study, a total of 60 subjects were included. Randomisation was done using simple randomisation technique.

Statistical Analysis- Data analysis was done with the help of computer using Epidemiological Information Package (Epi Info ver 3.5.1). Statistical test, independent sample ' $t$ ' test was used after ascertaining normality to test the hypothesis. A probability value (p) of $<0.05$ was to be considered as statistically significant.

\section{RESULTS}

There is high statistically significant difference in mean heart rate across the 2 groups $(p<0.001)$. The mean heart rate, blood pressure and mean arterial pressure of the esmolol group are the least. At 2 minutes following intubation, there is statistically significant difference in mean heart rate, mean systolic and diastolic pressure of patients across 2 groups ( $<<0.001$ ). The blood pressure and mean arterial pressure are lowest in the esmolol group than lignocaine. At 4 minutes following intubation, they are statistically significant. Patients in esmolol group are having significantly lower values than the lignocaine group. There is statistically significant difference in mean heart rate, blood pressure and mean arterial pressure of patients across 2 groups.

\section{CONCLUSION}

In this study, Esmolol has achieved a better attenuated rise in blood pressure when compared to lignocaine.

\section{KEYWORDS}

Esmolol, Lignocaine, Laryngoscopy, Endotracheal Intubation.

HOW TO CITE THIS ARTICLE: Jupalli SR, Sridhar I, Madhala K. Comparative evaluation of bolus administration of esmolol versus lignocaine for pressor response attenuation during laryngoscopy and endotracheal intubation. J. Evolution Med. Dent. Sci. 2017;6(72):5164-5167, DOI: 10.14260/Jemds/2017/1121

\begin{abstract}
BACKGROUND
Endotracheal intubation and anaesthesia have become an integral part of the anaesthesiologist's contribution to the patient care. Endotracheal intubation is the translaryngeal placement of endotracheal tube into the trachea. General anaesthesia procedures involve many stressful events at various stages. These are certain more stressful situations for the patient under general anaesthesia as regards to induction, intubation and extubation.
\end{abstract}

Financial or Other, Competing Interest: None.

Submission 30-07-2017, Peer Review 24-08-2017,

Acceptance 31-08-2017, Published 07-09-2017.

Corresponding Author:

Dr. Sridhar $I$

Assistant Professor,

Department of Pharmacology,

Government Medical College,

Nizamabad.

E-mail: dr.sridhar99@gmail.com

DOI: $10.14260 /$ jemds $/ 2017 / 1121$
Laryngoscopy and intubation is almost always associated with haemodynamic changes due to sympathetic discharge caused by epipharyngeal and laryngopharyngeal stimulation. This stimulation is associated with increase in plasma norepinephrine concentration. ${ }^{1}$ The circulatory perturbations consists of elevation in heart rate, systolic blood pressure, pulmonary arterial pressure and cardiac arrhythmias which occasionally lead to myocardial ischaemia, heart failure and cerebrovascular catastrophes in susceptible patients. In healthy patients, these responses are generally well tolerated.2,3,4

This response is undesirable and dangerous in patients with heart disease (limited coronary or myocardial reservemyocardial ischaemia or failure may follow), valvular heart disease, hypertension, cerebrovascular disease, intracranial vascular anomaly, abdominal aortic aneurysm, dissecting aortic aneurysm, pheochromocytoma, pre-eclamptic toxaemia, etc. In these patients, response to direct laryngoscopy and tracheal intubation results in an increase in cardiac workload, which in turn may culminate in 
perioperative myocardial ischaemia and acute heart failure. It may also lead to intracranial haemorrhage and raised intracranial pressure. It may precipitate convulsions in patients with preeclampsia. A relatively deep level of anaesthesia must be established to reduce cardiovascular response to laryngoscopy and intubation, because deep anaesthesia may not be tolerated by patients with above complications.

Strategies to circumvent these changes have includedMinimising the duration of laryngoscopy to less than 15 seconds-

- The use of topical and intravenous lignocaine, vasodilators (phentolamine and clonidine).

- Low dose fentanyl and alfentanil, inhaled anaesthetics,

- Beta blocking agents, etc.

Each technique has advantages and disadvantages, the most being that the prevention often outlasts the stimulus. Esmolol is a new beta blocking agent with several desirable properties. It may find a place in the anaesthesiologist's armamentarium than Lignocaine hydrochloride.

\section{Aims and Objectives}

A comparative clinical evaluation of intravenous $2 \%$ Lignocaine and Esmolol in attenuating the cardiovascular changes to laryngotracheal stimulation in healthy normotensive patients during a widely used method of induction of anaesthesia in order to reduce the lifethreatening complications in susceptible patients.

\section{MATERIALS AND METHODS}

\section{Methodology}

A randomised controlled study was conducted in Department of Anaesthesiology at Osmania General Hospital attached to Osmania Medical College from April 2015 to May 2016 (1 year) by using pre-designed, pre-tested questionnaire. Ethical clearance was obtained from Hospital Ethics Committee for the study and written informed consent was obtained from all the patients who were included in the study.

The sample size is calculated based on the primary outcome variable, i.e. Heart rate. To detect a difference of 20 beats/min and standard deviation of 40 which gives an effect size of 0.8 , considering Type I error $(\alpha)$ of $5 \%$ i.e. to detect a difference at the $95 \%$ confidence interval and Type II error ( $\beta$ ) of $20 \%$ i.e. with a power of $80 \%$ for the study keeping the ratio of two groups as 1 .

$$
\mathrm{n}=2\left(\mathrm{z}_{1-\alpha / 2}+\mathrm{z}_{1-\beta}\right)^{2} /\left(\mu_{0}-\mu_{1} / \sigma\right)^{2}
$$

The sample size per group is 26 . So the minimum sample size required for the study is 54 . In this study, a total of 60 subjects were included. Randomisation was done using simple randomisation technique. Step 1- Random numbers were obtained using Microsoft Excel 2007 and the sequence of random numbers thus obtained were kept safe.

Step 2- Recruiting into groups was done based on serial numbers matched with random numbers. It follows like thisfor the first subject (serial no. 1), if in the random number table the first one is odd he/she will be assigned to Group I and if suppose it is an even number in random number table then he/she will be assigned to Group II. In similar way, all the 60 patients were assigned.

\section{Group I}

Consists of 30 patients, where lignocaine hydrochloride 1.5 mg per kg IV bolus dose was used for attenuation of cardiovascular response to laryngoscopy and intubation.

\section{Group II}

Consists of 30 patients where esmolol hydrochloride $1.5 \mathrm{mg}$ per kg body weight IV bolus dose was used as study drug.

\section{Inclusion Criteria}

Patients with age more than 20 years, who have given consent were included.

\section{Exclusion Criteria}

Patients with history of respiratory problems, history of heart diseases, diabetes, hypertension and other major medical problems who are not giving consent.

\section{Statistical Analysis}

The information collected regarding all the selected cases were recorded in a Master Chart. Data analysis was done with the help of computer using Epidemiological Information Package (Epi Info ver 3.5.1). The categorical data was expressed as rates and proportions and quantitative data was expressed in means and standard deviation (SD). Statistical test, independent sample ' $t$ ' test was used after ascertaining normality to test the hypothesis. A probability value (p) of $<$ 0.05 was to be considered as statistically significant.

\section{RESULTS}

\begin{tabular}{|c|c|c|}
\hline Age Group (In Years) & Lignocaine Group & Esmolol Group \\
\hline $20-29$ & 9 & 9 \\
\hline $30-39$ & 11 & 10 \\
\hline $40-49$ & 5 & 7 \\
\hline $50-59$ & 5 & 4 \\
\hline Total & 30 & 30 \\
\hline Mean \pm SD & $37.2 \pm 10.15$ & $37.36 \pm 9.78$ \\
\hline
\end{tabular}

\begin{tabular}{|c|c|c|}
\hline Sex & Lignocaine Group & Esmolol Group \\
\hline Males & $14(47 \%)$ & $17(57 \%)$ \\
\hline Females & $16(53 \%)$ & $13(43 \%)$ \\
\hline Total & $\mathbf{3 0}(\mathbf{1 0 0} \%)$ & $\mathbf{3 0 ( 1 0 0 \% )}$ \\
\hline Table 2. Sex & Wise Distribution of Study Subjects \\
\hline
\end{tabular}

The sex composition of the two groups are nearly identical.

\begin{tabular}{|c|c|c|c|c|c|}
\hline $\begin{array}{l}\text { Basal } \\
\text { Rates }\end{array}$ & \begin{tabular}{|c} 
Lignocaine \\
Group
\end{tabular} & \begin{tabular}{c|} 
Esmolol \\
Group
\end{tabular} & $\begin{array}{c}\text { t- } \\
\text { Value }\end{array}$ & $\begin{array}{c}\text { P- } \\
\text { Value }\end{array}$ & $\begin{array}{c}\text { Significanc } \\
\text { e }\end{array}$ \\
\hline $\begin{array}{l}\text { Heart } \\
\text { Rate }\end{array}$ & $\begin{array}{l}87.4 \pm \\
11.85\end{array}$ & $\begin{array}{c}86.43 \pm \\
10.3\end{array}$ & 0.3384 & 0.7363 & $\begin{array}{c}\text { Not } \\
\text { Significant }\end{array}$ \\
\hline $\begin{array}{c}\text { Systolic } \\
\text { BP }\end{array}$ & $\begin{array}{l}127 \pm \\
8.43\end{array}$ & \begin{tabular}{|c|}
$127.96 \pm$ \\
9.47 \\
\end{tabular} & 0.4147 & 0.6799 & $\begin{array}{c}\text { Not } \\
\text { Significant }\end{array}$ \\
\hline $\begin{array}{c}\text { Diastolic } \\
\text { BP }\end{array}$ & $\begin{array}{c}82.86 \pm \\
4.9\end{array}$ & \begin{tabular}{|c|}
$81.33 \pm$ \\
5.21 \\
\end{tabular} & 1.1717 & 0.2461 & $\begin{array}{c}\text { Not } \\
\text { Significant }\end{array}$ \\
\hline $\begin{array}{c}\text { Mean } \\
\text { Arterial } \\
\text { Pressure }\end{array}$ & $\begin{array}{c}97.57 \pm \\
6.07\end{array}$ & $\begin{array}{c}96.87 \pm \\
6.63\end{array}$ & 0.4265 & 0.6713 & $\begin{array}{c}\text { Not } \\
\text { Significant }\end{array}$ \\
\hline \multicolumn{6}{|c|}{$\begin{array}{l}\text { Table 3. Mean Basal Heart Rate, Systolic Blood } \\
\text { Pressure, Diastolic Blood Pressure at the } \\
\text { Time of Laryngoscopy and Intubation }\end{array}$} \\
\hline
\end{tabular}


There is no statistical significance difference in the mean heart rate, mean systolic, mean diastolic blood pressure across 2 groups, $(\mathrm{P}>0.05)$.

There is no statistical significance difference in the mean heart rate, mean systolic and diastolic blood pressure at study drug too among 2 groups.

\begin{tabular}{|c|c|c|c|c|l|}
\hline $\begin{array}{c}\text { At } \\
\text { Intubation }\end{array}$ & $\begin{array}{c}\text { Lignocaine } \\
\text { Group }\end{array}$ & $\begin{array}{c}\text { Esmolol } \\
\text { Group }\end{array}$ & $\begin{array}{c}\text { t- } \\
\text { Value }\end{array}$ & $\begin{array}{c}\text { P- } \\
\text { value }\end{array}$ & $\begin{array}{c}\text { Significanc } \\
\mathbf{e}\end{array}$ \\
\hline $\begin{array}{c}\text { Heart } \\
\text { Rate }\end{array}$ & $\begin{array}{c}102.7 \\
\pm 11.99\end{array}$ & $\begin{array}{c}91.43 \\
\pm 10.15\end{array}$ & 3.9294 & 0.0002 & Significant \\
\hline $\begin{array}{c}\text { Systolic } \\
\text { BP }\end{array}$ & $\begin{array}{c}142.33 \\
\pm 12.10\end{array}$ & $\begin{array}{c}134.56 \\
\pm 8.04\end{array}$ & 2.9295 & 0.0048 & Significant \\
\hline $\begin{array}{c}\text { Diastolic } \\
\text { BP }\end{array}$ & $\begin{array}{c}94.26 \\
\pm 11.02\end{array}$ & $\begin{array}{c}88.86 \pm \\
6.46\end{array}$ & 2.3154 & 0.0241 & Significant \\
\hline $\begin{array}{c}\text { Mean } \\
\text { Arterial } \\
\text { Pressure }\end{array}$ & $\begin{array}{c}104.09 \\
\pm 6.98\end{array}$ & $\begin{array}{c}110.28 \pm \\
11.38\end{array}$ & 2.5396 & 0.0138 & Significant \\
\hline
\end{tabular}

Table 4. Mean Heart Rate, Systolic Blood Pressure,

Diastolic Blood Pressure and Mean Arterial Pressure at Laryngoscopy and Endotracheal Intubation

There is high statistically significant difference in mean heart rate across the 2 groups $(\mathrm{p}<0.001)$. The mean heart rate, blood pressure and mean arterial pressure of the esmolol group are the least. The differences with the lignocaine group are statistically significant.

\begin{tabular}{|c|c|c|c|c|l|}
\hline $\begin{array}{c}\text { At 1 } \\
\text { Minute }\end{array}$ & $\begin{array}{c}\text { Lignocaine } \\
\text { Group }\end{array}$ & $\begin{array}{c}\text { Esmolol } \\
\text { Group }\end{array}$ & $\begin{array}{c}\text { t- } \\
\text { Value }\end{array}$ & $\begin{array}{c}\text { P- } \\
\text { Value }\end{array}$ & Significance \\
\hline $\begin{array}{c}\text { Heart } \\
\text { rate }\end{array}$ & $\begin{array}{c}103.86 \\
\pm 12.48\end{array}$ & $\begin{array}{c}92.26 \\
\pm 10.08\end{array}$ & 3.9605 & 0.0002 & Significant \\
\hline $\begin{array}{c}\text { Systolic } \\
\text { BP }\end{array}$ & $\begin{array}{c}142.63 \\
\pm 12.02\end{array}$ & $\begin{array}{c}135.66 \\
\pm 8.11\end{array}$ & 2.6328 & 0.0108 & Significant \\
\hline $\begin{array}{c}\text { Diastolic } \\
\text { BP }\end{array}$ & $\begin{array}{c}94.9 \\
\pm 10.7\end{array}$ & $\begin{array}{c}88.86 \\
\pm 5.57\end{array}$ & 2.7425 & 0.0081 & Significant \\
\hline Mean & 110.81 & 104.46 & 2.7061 & 0.0089 & Significant \\
Arterial \\
Pressure & \pm 11.14 & \pm 6.41 & Table 5. Mean Heart Rate, Systolic Blood Pressure, \\
\hline \multicolumn{6}{|c|}{ Diastolic Blood Pressure and Mean Arterial } \\
Pressure at 1 Minute \\
\hline
\end{tabular}

There is statistically significant difference in mean heart rate of patients across 2 groups ( $p<0.001)$. Mean systolic and diastolic pressures are statistically significant among 2 groups $(\mathrm{p}<0.01)$. The blood pressure and mean arterial pressure are lowest in the esmolol group than lignocaine.

At 2 minutes following intubation, there is statistically significant difference in mean heart rate, mean systolic and diastolic pressure of patients across 2 groups $(p<0.001)$. The blood pressure and mean arterial pressure are lowest in the esmolol group than lignocaine.

\begin{tabular}{|c|c|c|c|c|c|}
\hline $\begin{array}{c}\text { At 3 } \\
\text { Minutes }\end{array}$ & $\begin{array}{c}\text { Lignocaine } \\
\text { Group }\end{array}$ & \begin{tabular}{|c|} 
Esmolol \\
Group
\end{tabular} & $\begin{array}{c}\mathrm{t}- \\
\text { Value }\end{array}$ & $\begin{array}{c}\text { p- } \\
\text { Value }\end{array}$ & Significant \\
\hline $\begin{array}{l}\text { Heart } \\
\text { Rate }\end{array}$ & $\begin{array}{l}96.88 \\
\pm 9.63\end{array}$ & $\begin{array}{l}88.06 \\
\pm 8.01\end{array}$ & 3.8568 & 0.0003 & Significant \\
\hline $\begin{array}{c}\text { Systolic } \\
\text { BP }\end{array}$ & $\begin{array}{l}134.2 \\
\pm 9.96 \\
\end{array}$ & & 2.6145 & 0.0114 & Significant \\
\hline Diastolic BP & $\begin{array}{c}88 \\
\pm 8.92\end{array}$ & $\begin{array}{l}81.13 \\
\pm 5.09 \\
\end{array}$ & 3.6639 & 0.0005 & Significant \\
\hline $\begin{array}{l}\text { Mean } \\
\text { Arterial } \\
\text { Pressure }\end{array}$ & $\begin{array}{l}103.4 \\
\pm 9.26\end{array}$ & $\begin{array}{l}96.84 \\
\pm 5.88\end{array}$ & 3.2756 & 0.0018 & Significant \\
\hline \multicolumn{6}{|c|}{$\begin{array}{c}\text { Table 6. Mean Heart Rate, Systolic Blood Pressure, } \\
\text { Diastolic Blood Pressure and Mean Arterial } \\
\text { Pressure at } 3 \text { Minutes }\end{array}$} \\
\hline
\end{tabular}

There is high statistically significant difference in mean heart rate, blood pressure and mean arterial pressure of patients across 2 groups ( $p<0.001)$. Patients in esmolol group are having significantly lower values than the lignocaine group.

At 4 minutes following intubation, there is statistically significant difference in mean heart rate, blood pressure and mean arterial pressure of patients across 2 groups $(\mathrm{p}<0.001)$. Patients in esmolol group are having significantly lower values than the lignocaine group.

\begin{tabular}{|c|c|c|c|c|l|}
\hline $\begin{array}{c}\text { At 5 } \\
\text { Minutes }\end{array}$ & $\begin{array}{c}\text { Lignocaine } \\
\text { Group }\end{array}$ & $\begin{array}{c}\text { Esmolol } \\
\text { Group }\end{array}$ & $\begin{array}{c}\mathbf{t}- \\
\text { Value }\end{array}$ & $\begin{array}{c}\mathbf{p} \\
\text { value }\end{array}$ & $\begin{array}{c}\text { Significan } \\
\text { ce }\end{array}$ \\
\hline $\begin{array}{c}\text { Heart } \\
\text { Rate }\end{array}$ & $\begin{array}{c}91.16 \\
\pm 9.54\end{array}$ & $\begin{array}{l}86.36 \\
\pm 8.32\end{array}$ & 2.0769 & 0.0422 & Significant \\
\hline $\begin{array}{c}\text { Systolic } \\
\text { BP }\end{array}$ & $\begin{array}{c}127.63 \\
\pm 7.40\end{array}$ & $\begin{array}{c} \pm 2.96 \\
\pm 8.99\end{array}$ & 2.1967 & 0.0320 & Significant \\
\hline $\begin{array}{c}\text { Diastolic } \\
\text { BP }\end{array}$ & 82.2 & 78.7 & 2.3428 & 0.0226 & Significant \\
\pm 6.2 & \pm 5.34 & & & \\
\hline Mean & 97.34 & 94.78 & 1.5079 & 0.1370 & Significant \\
Arterial & \pm 6.6 & \pm 6.55 & & & \\
Pressure & Table 7. Mean Heart Rate, Systolic Blood Pressure, \\
\hline \multicolumn{6}{|c|}{ Diastolic Blood Pressure and Mean } \\
Arterial Pressure at 5 Minutes \\
\hline
\end{tabular}

There is statistically significant difference in mean heart rate, blood pressure and mean arterial pressure of patients across 2 groups. Patients in esmolol group are having significantly lower values than the lignocaine group.

\begin{tabular}{|c|c|c|c|c|c|}
\hline $\begin{array}{c}\text { At 6 } \\
\text { Minutes }\end{array}$ & $\begin{array}{c}\text { Lignocaine } \\
\text { Group }\end{array}$ & $\begin{array}{c}\text { Esmolol } \\
\text { Group }\end{array}$ & t-Value & p-Value & Significance \\
\hline $\begin{array}{c}\text { Heart } \\
\text { Rate }\end{array}$ & $\begin{array}{c}87.1 \\
\pm 8.68\end{array}$ & $\begin{array}{c}87.63 \\
\pm 11.38\end{array}$ & 0.2028 & 0.8400 & $\begin{array}{c}\text { Not } \\
\text { Significant }\end{array}$ \\
\hline $\begin{array}{c}\text { Systolic } \\
\text { BP }\end{array}$ & $\begin{array}{c}128.06 \\
\pm 7.41\end{array}$ & $\begin{array}{c}128.03 \\
\pm 8.85\end{array}$ & 0.0142 & 0.9887 & $\begin{array}{c}\text { Not } \\
\text { Significant }\end{array}$ \\
\hline $\begin{array}{c}\text { Diastolic } \\
\text { BP }\end{array}$ & $\begin{array}{c}82.16 \\
\pm 4.9\end{array}$ & $\begin{array}{c}79.83 \\
\pm 4.50\end{array}$ & 1.9183 & 0.0600 & $\begin{array}{c}\text { Not } \\
\text { Significant }\end{array}$ \\
\hline $\begin{array}{c}\text { Mean } \\
\text { Arterial } \\
\text { Pressure }\end{array}$ & $\begin{array}{c}97.46 \\
\pm 5.73\end{array}$ & $\begin{array}{c}95.89 \\
\pm 5.28\end{array}$ & 1.1036 & 0.2743 & $\begin{array}{c}\text { Not } \\
\text { Significant }\end{array}$ \\
\hline
\end{tabular}

Table 8. Mean Heart Rate, Systolic Blood Pressure, Diastolic Blood Pressure and Mean Arterial Pressure at 6 Minutes

There is no statistical significant difference in mean heart rate, mean systolic and diastolic blood pressure among patients in esmolol and lignocaine groups.

The peak increase in heart rate, systolic blood pressure and diastolic blood pressure noticed during laryngoscopy and endotracheal intubation in control group took 6 mins to reach the pre-induction value. In lignocaine group, mean heart rate took about 6 mins to reach the pre-induction value, whereas the mean systolic, diastolic blood pressure took about $4-5$ minutes to reach the pre-induction value. In esmolol group mean heart rate, mean systolic, diastolic blood pressure reached the pre-induction values within 3 minutes.

\section{DISCUSSION}

Laryngoscopy and endotracheal intubation frequently induce a cardiovascular stress response characterised by hypertension and tachycardia. This sympathoadrenal stress response to laryngoscopy results in an increase in myocardial 02 demand leading to ischaemia and acute heart failure in susceptible individuals. In view of the frequent occurrence of 
hypertension and tachycardia during laryngoscopy, even in normotensive individuals it is perhaps rather surprising that complications have not been met very often. One reason for this may be the transient nature of hypertension which usually lasts less than 10 minutes. It is possible however that some of the complications that can occur during intubation or even later in the course of anaesthesia may be precipitated by an episode of hypertension and tachycardia following endotracheal intubation. ELLIOF (1980) observed left ventricular wall dysfunction following endotracheal intubation.

This reflex sympathetic response may be diminished or modified locally, centrally and peripherally and attempts have been made to accomplish this using all these approaches with varying success. In an attempt to blunt these potentially adverse haemodynamic responses, different techniques and agents were used by many with varying success.

King et al (1951) used ether, Denlinger JK (1974) and Stoelting (1978) used a combination of viscous lignocaine and topical intratracheal lignocaine.5,6,7

J Curran et al (1980) tried droperidol, Richard et al (1981) studied the effect of $\beta$-blockers using metoprolol and propranolol respectively. 8,9

The factors favouring its value in obtunding the responses to laryngoscopy and endotracheal intubation include (M. Vucevic et al 1992). ${ }^{10}$

Esmolol 1 to $2 \mathrm{mg} / \mathrm{kg}$ is reliably effective in attenuating HR response to tracheal intubation than lignocaine: This is as per a double-blind, controlled, clinical trial, Kovac AL et al. ${ }^{11}$

Esmolol $1.5 \mathrm{mg} / \mathrm{kg}, 2$ minutes before intubation prevents tachycardia and an increase in RPP caused by laryngoscopy and tracheal intubation and can be beneficial when administered before laryngoscopy and tracheal intubation in patients with tachycardia. This confers with the study of Ugur, et al. 12

Esmolol $1.5 \mathrm{mg} / \mathrm{kg}$ is superior to lignocaine $(1.5 \mathrm{mg} / \mathrm{kg})$ for attenuation of haemodynamic response to laryngoscopy and endotracheal intubation. Therefore, we can conclude that patients with hypertension, ischaemic heart disease and brain tumour will be benefitted by giving intravenous esmolol preoperatively before laryngoscopy and endotracheal intubation.

With esmolol, mean systolic and diastolic blood pressure returned to baseline value within 3 minutes after intubation. This is in accordance with the study of M Helfman et al (1991).13

\section{CONCLUSION}

In this study, Esmolol has achieved a better attenuated rise in blood pressure when compared to lignocaine. Esmolol has got good attenuation of sympathoadrenal response accompanying laryngoscopy and endotracheal intubation in comparison with lignocaine. Thus, esmolol a cardioselective $\beta$-blocker is a better alternative for attenuation of sympathoadrenal response during laryngoscopy and endotracheal intubation.

\section{REFERENCES}

[1] Sheppard D, DiStefano S, Byrd RC, et al. Effects of esmolol on airway function in patients with asthma. The Journal of Clinical Pharmacology 1986;26(3):16974.

[2] Stoelting RK. Attenuation of blood pressure response to laryngoscopy and tracheal intutation with sodium nitroprusside. Anesthesia \& Analgesia 1979;58(2):116-9.

[3] Miller DR, Martineau RJ, Wynands JE, et al. Bolus administration of esmolol for controlling the haemodynamic response to tracheal intubation: the Canadian multicentre trial. Canadian Journal of Anesthesia/Journal Canadien D'anesthésie 1991;38(7):849-58.

[4] Fox EJ, Sklar GS, Hill CH, et al. Complications related to the pressor response to endotracheal intubation. Anesthesiology 1977;47(6):524-5.

[5] King BD, Harris LC, Greifenstein FE, et al. Reflex circulatory responses to direct laryngoscopy and tracheal intubation performed during general anesthesia. Anesthesiology 1951;12(5):556-66.

[6] Denlinger JK, Ellison N, Ominsky AJ. Effects of intratracheal lidocaine on circulatory responses to tracheal intubation. Anesthesiology 1974;41(4):40912.

[7] Stoelting RK. Circulatory changes during direct laryngoscopy and tracheal intubation: influence of duration of laryngoscopy with or without prior lidocaine. Anesthesiology 1977;47(4):381-4.

[8] Curran J, Crowley M, O'Sullivan G. Droperidol and endotracheal intubation. Attenuation of pressor response to laryngoscopy and intubation. Anaesthesia 1980;35(3):290-4.

[9] Gorczynski RJ. Basic pharmacology of esmolol. The American Journal of Cardiology 1985;56(11):F3-F13.

[10] Vucevic M, Purdy GM, Ellis FR. Esmolol hydrochloride for management of the cardiovascular stress responses to laryngoscopy and tracheal intubation. British Journal of Anaesthesia 1992;68(5):529-30.

[11] Kovac AL. Controlling the hemodynamic response to laryngoscopy and endotracheal intubation. Journal of Clinical Anesthesia 1996;8(1):63-79.

[12] Ugur B, Ogurlu M, Gezer E, et al. Effects of esmolol, lidocaine and fentanyl on haemodynamic responses to endotracheal intubation. Clinical Drug Investigation 2007;27(4):269-77.

[13] Helfman SM, Gold MI, DeLisser EA, et al. Which drug prevents tachycardia and hypertension associated with tracheal intubation: lidocaine, fentanyl or esmolol? Anesthesia \& Analgesia 1991;72(4):482-6. 